\title{
Smart schools on the way: How school principals from Catalonia approach the future of education within the fourth industrial revolution
}

\author{
Jordi Mogas $^{1}$ (D) $\cdot$ Ramon Palau $^{1} \cdot$ Marta Fuentes $^{2} \cdot$ Gisela Cebrián $^{1}$
}

Received: 8 September 2020 / Accepted: 26 October 2021 / Published online: 5 November 2021 (c) The Author(s) 2021

\begin{abstract}
The advent of the Fourth Industrial Revolution is introducing developments in Artificial Intelligence, Internet of Things, and other technologies in different sectors of our society, including education. This reality leads to a paradigm shift in which web-based cyber-physical environments will shape future learning environments. Thus, learning becomes ubiquitous, and schools assume new roles with systemic changes in communication, administration and management, becoming learning organisations. The use of technologies aligned with pedagogical strategies and new methodologies must lead to more-personalised systems. In this article, a comprehensive definition of smart schools is proposed. Smart schools must be endowed with integral management systems, inclusive, sustainable, and adopt new learning methodologies and advances from Industry 4.0 in an efficient way. Despite this conception and because research, government policies and business projects are not always in line with research, there is a need for deeper knowledge of how schools are approaching their upcoming transformation. To illuminate this purpose, in this study 37 principals from primary and secondary schools in Catalonia were interviewed. Thematic analysis focusing on technological and pedagogical innovations, management systems, inclusion, and sustainability identified some analogies with related research, pointing out that schools are far from implementing advanced technologies. Inclusion is the most-respected element thanks to the existing government regulation. Sustainability is hardly considered because of a lack of economic resources, but several schools consider themselves green schools and exhibit environmental practices. Conclusions are drawn to show that, although schools are not yet prepared to cope with the Fourth Industrial Revolution, its impact relies on the technology's level of maturity and ease of use, as well as stakeholders as policymakers.
\end{abstract}

Keywords Fourth industrial revolution · Industry 4.0 Learning environment $\cdot$ Smart classroom $\cdot$ Smart school

Jordi Mogas

jordi.mogas@urv.cat

1 Department of Pedagogy, Universitat Rovira i Virgili, Tarragona, Spain

2 Universitat Autònoma de Barcelona, Barcelona, Spain 


\section{Introduction}

Technological achievements have had a significant impact on education and new learning developments over the past 40 years, along with active research in neuroscience, psychology and fields involving cognition (Sah et al., 2016). The presence of Information and Communication Technologies (ICT) in schools is continuously increasing (Hassan \& Geys, 2016). Many countries around the world, including developing countries, are investing in bringing ICT equipment and resources into schools, including those with limited financial resources (Kozma \& Vota, 2014). But is such investment useful?

On many occasions, schools have to choose resources and tools without deep knowledge of their potential and functionalities, although integration should go beyond simply providing technological components (Ifenthaler \& Schweinbenz, 2016). A challenge remains in all countries in terms of how public investment for ICT in education should have a greater impact on students' learning (Zhang et al., 2016) and how it is adopted in a critical and adequate way. At a classroom level, up to three groups of teachers with different degrees of favourableness towards ICT inclusion to promote smart learning spaces can be identified to characterise contradictory perceptions (Bautista et al., 2021). Some aspects remain under research, such as the ethical implementation of technology in education, social inclusion, and the digital divide. In the present paper, the approach of advanced technology for smart classrooms presented by Lorenzo et al. (2021) is broadened and deepened to focus on the convenience of a critical implementation of technologies in schools in terms of inclusion, personalisation as a complement to collective learning, and ethics when introducing advanced technologies.

With so many innovations related to the availability of computers in schools, it is paradoxical that digitalisation has made ICT ubiquitous. However, the use of these technologies in schools is moderate (Vincent-Lancrin et al., 2019). Future learning spaces are envisioned by some authors as dynamic and technology-rich in order to cope with hybridity (i.e. sources of learning that combine the physical learning environments and online learning anytime and anywhere) (Eyal \& Gil, 2020). Technology must be used as a tool to improve education because the grounds for the change are pedagogical and not merely technological (Mogas et al., 2020); it would be fruitless, distracting or even counterproductive if change leads to unwanted situations such as social isolation if personalisation promotes uncontrolled individualism. Learning personalisation is not inherently favourable.

The OECD (2017b) established principles for innovative learning environments and argued for the need to consider the concept of 'learning environments' rather than 'schools' or 'classrooms', reinforcing a focus on the learning organisation in its whole conception, not only on the institution and physical places where learning formally happens. To be innovative, schools must become "learning organisations" as a number of scholars, educators, and policy-makers makers have already argued (OECD, 2017a; Senge, 2006). Schools need to lead innovation processes to become key stakeholders in the decision-making processes (OECD, 2017b). In this context, educational leadership is key to changing the existing culture of educational organisations (Bryk et al., 2009; Gu \& Johansson, 2013; ten Bruggencate et al., 2012). Schools as learning organisations should move from technical solutions to the creation of organisations where individuals learn to continually improve their own situation. A learning organisation is based on lifelong and team learning amongst its members and is defined as an organisation where 
"its members continually expand their capacity to create the results they truly desire, where new and expansive patterns of thinking are nurtured, where collective aspiration is set free, and where people are continually learning how to learn together" (Senge, 2006, p. 3).

The dynamics of technological developments in education require people to gain new digital skills and adapt to new situations (Zulkarnaen et al., 2019). The paradigm shift in learning organisations inevitably requires a change from teachers. Teaching is considered a process for initiating, facilitating, and sustaining self-learning, self-exploration, and selfrealization of students; therefore, teachers must play a key role as facilitators or mentors who are capable of supporting studente learning with technology (Ibrahim et al., 2013). Teachers must use innovative pedagogies combined with the redesign of learning environments (Paniagua \& Istance, 2018) to allow change in the role of leadership. Organisations need to be able to continually adapt to changes in their environment. Thus, for an organisation, learning and its members' ability to learn and adapt are essential for building the capacity required to deal with their external environment and be able to survive and sustain activities over time (Senge, 2006).

Within this paradigm shift, the idea of smart learning environments (SLE) is gaining attention in the scientific literature. To be considered smart and provide effective solutions, a learning environment must allow identification of learners' characteristics, provide necessary resources and tools, automate learning processes, and evaluate their outcomes Huang et al., 2013). SLE uses digital, adaptive, and environment-aware devices to promote faster and better learning (Koper, 2014), as well as providing insights into improving teaching work conditions. For this purpose, the background presented in this article deepens understanding of how technologies from the Fourth Industrial Revolution (4IR) affect such environments and smart education. 4IR technologies comprise the Internet of Things, cloud computing, artificial intelligence, and others. Artificial intelligence has achieved success in terms of technological developments over the past 25 years (Roll \& Wylie, 2016), and how it is introduced into schools is currently being explored.

Smart schools involve these technological innovations in schools being complemented with pedagogical innovation, improved communication and management processes, and inclusive designs and decisions towards sustainability. The smart school directly deals with four of the Sustainable Development Goals (United Nations, 2019) of high-quality education (goal 4), industry, innovation and infrastructure (goal 9), reducing inequalities (goal 10), and sustainable cities and communities (goal 11). Sustainable development promotes equity, social justice and environmental practices that sustain biodiversity and ecological processes (United Nations, 2012) and works towards achieving ethical individuals, collaborative communities and social systems and institutions that are participatory, transparent, and just (Hill et al., 2004).

Advances in the conceptualisation of smart classroom and smart school concepts take into account the need for these spaces to be inclusive, thereby boosting the paradigm change and avoiding repeating the capitalist paradigm through the implementation of technology in education (Means, 2018). Thus, schools have at their disposal technological advances, but it is unclear how they are taking advantage of them. Published research does not cover adequately how schools are comprehensively tackling the possibilities enabled by the 4IR (Oke \& Fernandes, 2020). It seems that independent actions are happening in line with smart school principles, but not in a structured and cohesive way. Our work started from the hypothesis that schools in Catalonia are depending on some decisions in line with the concept of smart school, but in a fragmented way without a defined and common framework to guide the strategy. Therefore, our main objective was to identify the 
transition of Catalan schools towards smart schools from a holistic viewpoint and to identify how schools are facing future education mediated by technology, which actions are already being undertaken, and how to cope with the future. In the following sections, background for conceptualising Industry 4.0 and smart schools is provided, research methods are outlined, results are reported and discussed, and conclusions from this study are drawn.

\section{Background}

\section{Educational shift arising from Industry 4.0}

Because modern education is not sufficiently influencing the development of human capital in digital environments (Lyapina et al., 2019), therefore smart education addresses the need to improve physical learning environments through the potential of technological advances (Karampa \& Paraskeva, 2020). Since the eighteenth century, consecutive industrial revolutions allowed huge improvements in manufacturing and mass production thanks to cast iron production, steam engines, advances in the textile industry, combustion engines, and electricity. The Third Industrial Revolution arrived in the decade of 1980 thanks to the popularisation of electronic devices such as personal computers, telecommunication, and developments in computer science. Nowadays, evolution is becoming more complex and merges physical reality with virtuality into a new conception of web-based cyber-physical interconnected systems (Ng, 2020; Zhong et al., 2017). This new paradigm shapes the Fourth Industrial Revolution (4IR) and brings unexplored possibilities in relation to educational automation and optimisation processes. Learning environments can be synchronous hybrid or blended, with both on-site and remote students interacting and participating in learning activities as if they are in the same place (Raes et al., 2019) and with all objects of the learning organisation being interconnected and connected and to internet to allow advanced systems of approaching smart education. This paradigm brings new educational possibilities but also important ethical issues related to surveillance, data protection and control, and the involvement of children and youngsters that must be carefully considered, conceptualised, and investigated through evidence-based research (Spector, 2016).

The 4IR and Industry 4.0 are often used as synonym concepts (Nosalska et al., 2019). Firstly, named back in 2015 by Klaus Schwab (2017) who is founder and executive chairman of the World Economic Forum, the 4IR refers to the inclusion of the newest technologies to improve manufacturing and production processes. In application to the traditional industry, 4IR affects other fields including medicine and healthcare, biology, civil structures, autonomous vehicles, and power distribution $(\mathrm{Ng}, 2020)$, as well as education (Mogas et al., 2020). The education sector can use technologies from 4IR to foster the learner-centred approach necessary to enhance the learning experience (Oke \& Fernandes, 2020). More concretely, technologies identified within Industry 4.0 include 3D printing, virtual reality and augmented reality, gamification, cloud computing, robotics, Internet of Things (IoT), artificial intelligence, big data, blockchain, wearable devices, and eye-tracking (Rodal, 2020). In this context, it is important to define how the new educational paradigm within the context of the 4IR is used, with special attention to social inclusion and ethical issues (Hoel \& Mason, 2018; Means, 2018; Moore \& Ellsworth, 2014).

Artificial intelligence is acknowledged by the European Commission (2020) as a facilitator to bring high-impact innovations to education. It is anticipated that learning analytics and artificial intelligence will provide data from learning processes to adapt solutions for 
every moment and student to create adaptive teaching and learning paths; however, to date, solutions need to be improved (Renz \& Hilbig, 2020). Improvements could involve either technology improvement or critical perspectives that prevent a profit-driven standardisation of learning.

According to published research, artificial intelligence for education can be used in academic support services and to support institutional and administrative services in four main areas: profiling and prediction, assessment and evaluation, adaptive systems and personalisation, and intelligent tutoring systems (Zawacki-Richter et al., 2019). Internet of Things (IoT) permits the interconnection of physical objects with the cloud to provide greater control and interaction through sensor nodes, augmented reality, and other technologies (Gilman et al., 2020). IoT aims for a better organisation so that students learn faster and teachers have better working conditions. It can be in the form of smart digital boards, interactive learning, mobile devices and tablets, educational apps, electronic books that introduce the best way to learn, wireless locks on doors, advanced security measures, temperature sensors, attendance tracking systems, and others (Abdel-Basset et al., 2019). Cloud computing is not limited to cloud storage, but it also facilitates processing and presenting big data collected by IoT or any other process of e-learning in a sort of online data centre with the benefits of global access and scalability (Humayun, 2020). Artificial intelligence, IoT, and cloud computing are solutions fed by big data gathered using different types of sensors ranging from learning management systems tracks to contactless technologies and specific sensors to control environmental factors, eye-tracking systems (Sun \& Hsu, 2019), or wearables to provide teachers with students' physical data in real time (Liang et al., 2020).

In terms of more-popular technologies, the literature encompasses the inclusion of educational robotics, virtual reality, and augmented reality in concrete learning experiences (Anwar et al., 2019; Bacca et al., 2014; Maas \& Hughes, 2020), but smart education requires further implementation. In the case of robotics, robots can be used to help processes in teaching science or languages, considering user experiences, learning gains, attitudes, and usability (Papadopoulos et al., 2020). Virtual reality can promote new methodologies of teaching, such as simulations thanks to the immersion experience with virtual presence and augmented reality (using mobile devices or head-mounted displays), to provide enriching learning experiences if the learning content and the approach are appropriate (Elkoubaiti \& Mrabet, 2018). These technologies, apart from being innovative in schools because they provide new ways for teaching and learning, should allow new conceptions of information management and students' attendance.

The arrival of 4IR in the education sector has the potential to allow smart education to be more effective. Smart education or smart pedagogy is primarily intended for student personalisation (Lorenzo \& Gallon, 2019) both at the individual and group levels. Personalising each student's path and individualising training is essential in smart education Dneprovskaya et al., 2020), as is granting cohesion and adaption to the collective. This personalisation does not limit benefits of open-ended social and environmental engagement, creative pedagogies, critical thinking, ethical cultivation, and other key aspects of what high-quality learning environments can offer for children and young people. Rather, scaling-up possibilities convert traditional learning spaces into more-inclusive and sustainable learning spaces to create learning organisations (Senge, 2006). Recommendation systems are being explored for: predicting student performance by mining educational data on students' records, their motivation and socioeconomic data (El Hajji et al., 2019); offering personalised recommendations and prototype designs of network teaching resource systems (Li et al., 2019; Zhang et al., 2019), and reducing failure (El Mrabet \& Moussa, 2019). 


\section{Smart schools}

The use of Industry 4.0 solutions must be considered holistically together with systemic changes in SLE and in schools as learning organisations (Mogas et al., 2020). Because smart schools are still an exploratory field of research and innovation, the most-common advances come mainly from specific smart services such as ICT, devices and tools for presenting content, automatic student engagement-enhancement techniques, automatic assessment of student submissions, student attendance management methods, and adaptive physical environment systems (Saini \& Goel, 2019). In any case, smart schools are continuously adapting their capabilities along with the changing conditions of the information age (Omidinia et al., 2012) and improvements must be global and help all management processes.

A comprehensive definition for smart schools is proposed in this study. Smart schools must be endowed with integral management systems and automated solutions, people centred, inclusive, and sustainable, aiming to host smart education by efficiently adopting new learning methodologies and advances from the 4IR (Fig. 1).

The first element of smart schools is technology. To gather data, smart schools normally provide the building with sensor networks that house education in an ubiquitous way (de Freitas et al., 2019) with the use of IoT and cloud computing. Industry 4.0 is a strategic key in favour of pedagogical change (Lorenzo \& Gallon, 2019), easing communication and management of all sorts of processes in the learning organisation, from learning gains to building efficiency (Salimi \& Ghonoodi, 2012). While offering automated processes is the ultimate goal, the current state of Industry 4.0 allows initial improvements such as the Smart Schools Management System (SSMS), which was developed in Malaysia for school administrators to manage all aspects (resources and processes) required to support teaching and learning, including administrative functions as lesson schedules, programming activities, and computerised student academic records (Salimi \& Ghonoodi, 2012). The intensive use of technology in smart schools makes systemic change more integrated and automatable, people centred and sustainable.

The second element of smart schools is inclusion. Inclusive education entails (1) specific support measures to meet individual needs, (2) learning and participation opportunities for individuals via differentiated teaching methods in accessible formats, (3) assistive devices and required support services, and (4) empowerment of all students, particularly those from vulnerable groups including people with learning, developmental or intellectual disabilities (Brenes et al., 2018). Also, the Universal Design for Learning (UDL) guidelines are considered a reference framework for improving and optimising teaching

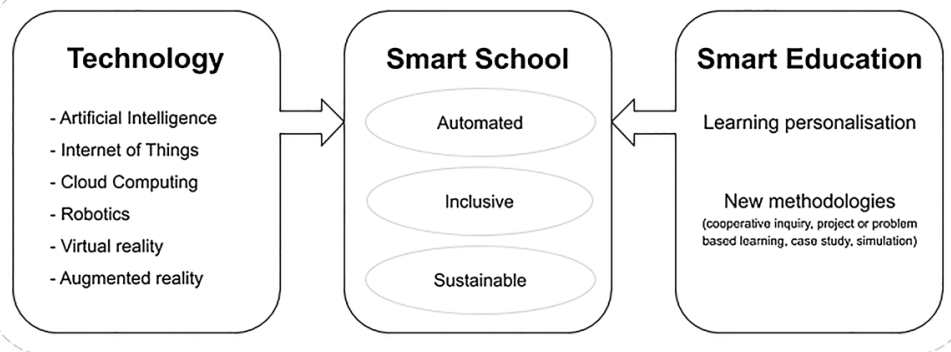

Fig. 1 Key elements for smart schools 
and learning of all individuals independent of their particular capacities and needs (CAST, 2018). Accessible education focuses on aspects such as the physical environment of schools, communication and language, learning materials, assessment of students, support for individual needs, mobility, and assistive devices or technologies (Booth \& Ainscow, 2002). The inherent presence of digital technologies should allow schools to be smarter in three aspects: without architectural barriers, applying UDL principles, and fostering personalisation of learning.

The third element of smart schools is sustainability. Sustainability for smart schools encompasses energy efficiency, environment regulation methods and any aspect needed to achieve buildings that are sustainable and environmentally friendly. School buildings can use IoT infrastructures to provide real-time monitoring and management to address both energy efficiency and educational issues (Pocero et al., 2017). In regard to environmental factors, a growing number of initiatives involve measuring lighting parameters, acoustic levels, air quality, temperature and humidity in classrooms (Saini \& Goel, 2019). Colour temperature must be adaptive in smart settings because a cold lighting atmosphere makes students more attentive, while warm lighting promotes creativity; therefore, dynamic lighting systems are proposed (Sleegers et al., 2013).

Smart education allows smart schools to have more-personalised learning within the learning environment. Personalisation requires new methods for teaching and learning. Trending methodologies related to smart education in smart classrooms are cooperative inquiry, project or problem-based learning, case study and simulation (Cebrián et al., 2020), which must allow individual and collective personalisation of learning and the active involvement of students in the learning process to promote personal and community well-being and fulfilment. The Teaching and Learning Toolkit presented by the Education Endowment Foundation (2018) shows feedback as one of the relevant elements that promotes better teaching and learning at little cost and supports learning environments, with technologies (if ethics are respected) possibly easing the task. Creating such spaces can offer children and youngsters the opportunity to engage in social and environmental issues, alternative pedagogies, citizen engagement and empowerment, pro-environmental and ethical competencies such as critical thinking, interpersonal competence and systemsthinking, which all improve the quality of learning environments (Bransford et al., 2004; Cebrián et al., 2020).

Governments are key for promoting the change process in education because they determine the policies, actions, structure and distribution of learning opportunities, as well as generating coherence of goals, infrastructure and accountability (OECD, 2017b). In Catalonia, laws and political guidelines cover separately the main topics related to smart schools (technology, inclusion, and sustainability). Technology is less regulated, but several reports offer orientations and recommendations about how to transform the school and implement technology. 'Digital Education Plan for Catalonia 2020-2025' seeks to weave a digitallycompetent network of schools with digitally-competent students and teachers (Generalitat de Catalunya, 2019). Regarding Industry 4.0 technologies, there are no actions for deployment in education, but a global strategy named Catalonia.AI already predicts that: "Education will be profoundly transformed by artificial intelligence by modifying teaching tools, forms of learning and access to knowledge. Thanks to artificial intelligence, we will be able to provide support to teachers and students for a more flexible and personalised education" (Generalitat de Catalunya, 2020, p. 49). Inclusion in schools is regulated in a law involving educational care for students within the framework of an inclusive education system (Decret, 150/2017). This law describes the functions of the education administration and schools, as well as all necessary measures, supports and resources. Two proposed services 
to support school inclusion are the Psychopedagogical Advice and Guidance Teams and the Intensive Supports for Inclusive Schooling. The need to embed sustainability within schools has also been acknowledged by the Catalan Government through the creation of a network of schools for sustainability and the Green Schools programme, which includes as key action areas 'greening' of the curriculum, environmental management, active participation and engagement of school agents and community, and service-learning.

\section{Related projects and experiences}

Several research projects are being developed worldwide in the light of smart classroom research, design and implementation. For example, in Catalonia, the Smart Classroom Project (https://smartclassroomproject.com/) is a research project that is led by Universitat Oberta de Catalunya and involves smart classrooms being co-creating and implemented in different schools to focus effort on space design, its flexibility and the way in which the classroom allows learning. In Spain, the inter-university project SmartLET (2020) aims at "improving the support of (re)design and orchestration of physically-situated scenarios based on different devices and massive scenarios within the context of SLEs by means of learning analytics" (https://smartlet.gsic.uva.es). Also, in the United States, Indiana University convened a so-called Smart Classroom Working Group to investigate smarter solutions "to build a learning environment that anticipates and automates common classroom tasks to make better use of faculty and student instructional time" (Johnston, 2018). At City University of Hong Kong, the Smart Classroom Initiative (https://www.cityu.edu. hk/smartclass/) explored the adoption of emerging technologies such as virtual reality for teaching and learning.

Governments are also deploying initiatives of smart education and smart schools. In the United States, New York State presented Smart Schools NY (https://www.ny.gov/progr ams/smart-schools-ny), program funded with $\$ 2$ billion to enhance teaching and learning through technology (New York Smart Schools, 2014). In Malaysia, efforts are being made by the government to turn schools smart by enabling technologies to foster the workforce of the twenty-first century (Zhu et al., 2016). In Korea, smart schools have been considered during the last years, and even the Ministry of Land, Infrastructure, and Transport and the Korea Education Research and Information Service have started a reform along these lines (Cho et al., 2020). The development of smart schools in China is at an initial stage (Wu et al., 2019), but initiatives to introduce technology are being reported.

The labels 'smart classroom' and 'smart school' also can be used to attract attention or merely to indicate inclusion of technology, often in less-developed countries or special areas. Examples are Iken Smart Classrooms in India (https://www.lghsvapi.edu.in/ content/iken-smart-classroom), a project implemented by founder Shri L. G. Haria in his Multipurpose School. It involves basic digital solutions for classrooms which, in their context, make a big difference in enhancing learning mediated by technology (Haria, 2020). Devotra Smart Classrooms (https://www.smartclassroom.nl) is a Dutch initiative for bringing devices and basic technology for education to different countries in Africa. Big companies and organisations are involved in projects. LG invested in Colombia with the Smart classroom initiative to bring devices to classrooms (LG CNS, 2014). The INTEF (Instituto Nacional de TecnologíasEducativas y de Formación de Profesorado del Ministerio de Educación y FormaciónProfesional) is collaborating with Samsung Spain in the Samsung Smart School (https://www.samsung.com/es/tecnologiaconproposito/samsung-conla-educacion/smart-school/) program to bring technology to rural areas of Spain and thus 
reinforce learning through smart devices (Camacho, 2019). Also, during the last decade, IBM considered transformative technologies for smarter education systems such as open technologies, cloud technology and consumer IT for a more-personalised learning, studentcentric processes, and openness, for all institutions and stakeholders (IBM Global Education, 2009).

Comparing research and implementation in schools (from government initiatives to business projects), the previous examples show that we are far from adopting Industry 4.0, artificial intelligence, Internet of Things and cloud computing in education. Further empirical research is needed to provide evidence about the implementation of smart schools, and the opportunities and challenges faced by school leaders ( $\mathrm{Gu} \&$ Johansson, 2013; ten Bruggencate et al., 2012). Our study provides a deeper analysis beyond specific examples to improve understanding of how schools in Catalonia are facing the emerging adoption of technology regarding the smart school paradigm.

\section{Method}

This research was undertaken with primary and secondary school principals in the region of Catalonia in Spain. The schools were selected using convenience sampling criteria of diversity within the chosen context, only limited by their voluntary availability to participate in this study. A qualitative methodology was selected because the aim was to gain a deep comprehension of the perceptions of school principals of technology adoption and topics related to their educational leadership (Flick et al., 2004). Qualitative research focuses on gaining a profound understanding of social situations (Creswell, 2007), with the data collected through qualitative research instruments such as interviews. Data are based on participants' experiences and tacit knowledge, which provide detailed information of specific phenomena (Denzin \& Lincoln, 2011; Silverman, 2006). A total of 37 semi-structured interviews were conducted with school principals and managers between April and June of 2020. The schools participating in this study comprised: 25 primary schools, 18 secondary schools (8 schools cover both levels), and 2 specialised schools (Music and special education). 31 are public schools and 6 schools are partially funded.

A semi-structured interview approach was chosen to allow deep understanding of the problem being researched through documenting participants' experiences (Kvale \& Brinkmann, 2009; Minichiello et al., 1990). The interviews included main themes for discussion, using open-ended questions, and allowed school principals to talk in-depth about the use of technology within their schools. Interview questions were related to: technological and pedagogical innovations carried out; use of technological systems to improve communication with families and the management of and coordination between teachers; inclusion initiatives that affect school facilities and resources; innovations in school facilities towards sustainability; and the needs, challenges and resistances identified in the adoption of innovative methods supported by the use of ICT.

Interviews were coded and analysed using Atlas.ti Cloud qualitative data analysis software. The analysis consisted of a coding process, comparing the codes and identifying emerging themes (Braun \& Clarke, 2006). A thematic analysis approach was used (Braun $\&$ Clarke, 2006) to make sense of the data collected during the research. This approach was chosen because it allowed a deep analysis and explanation of the data and the creation of key themes that participants considered relevant to how sustainable technological and pedagogical innovations can be implemented within their schools. Themes were created 
according to the significance and occurrence across the interviews and represent a rich account and overview of the data set and all of the factors that emerged.

\section{Findings}

\section{Technological innovations}

A common response related to technological innovation in schools involving the use of digital devices (desktop computers, laptops, tablets, iPads, Chromebooks and interactive panels or interactive whiteboards), Wi-Fi and LMS to complement other services (webpages, blogs, given software or apps, and cloud storage). These responses often expressed limitations with technological equipment: "The technologies used are limited to computers or mobile phones" (Participant 13) or "The use of new technologies in the student learning process is minimal: notebooks, computers and projectors in each classroom" (Participant 8). Some interviewees commented on frequent changes and updating:

We have promoted the implementation of technologies, with a long journey: first projectors in all classrooms, which were replaced by interactive whiteboards and now by interactive panels; computers in all classrooms, mini laptops, two computer rooms, tablets, etc. and all that its use entails, which is a change in the way it works. (Participant 10)

It is usual to report advances in basic technology advances in schools (Vincent-Lancrin et al., 2019). Robotics and programming were mentioned by 11 participants (e.g. Bee bot, Lego We-DO, Lego Robotics, Scratch). Only three school principals mentioned augmented reality and/or virtual reality, whilst one principal considered this possibility in the near future. These more-advanced proposals also appear to be common in other contexts (Anwar et al., 2019; Maas \& Hughes, 2020), but applied to concrete learning experiences without comprehensively addressing the challenge of rethinking the whole system while social inclusion and ethical issues are taken into account.

Interviewees were asked to list technological innovations. Pedagogical innovations are identified above, but misuses of technological devices were also reported during the interviews: "Some classrooms have interactive whiteboards, but sometimes they are used as simple projectors" (Participant 7). Some principals referred to common devices as "new technologies': "Depending on the level of education, new technologies are used, especially in secondary education. We use tablets, mobile phones and computers" (Participant 5) and showed self-awareness: "Can the use of computers still be considered an innovation?" (Participant 11). No principal considered artificial intelligence, Internet of Things, cloud computing (and not just cloud storage), wearable devices, sensors or eye-tracking as innovation in schools.

\section{Pedagogical innovations}

Principals felt at ease when asked about pedagogical innovations and reported their efforts to modify teaching. The new methodologies most-frequently commonly identified were Project Based Learning (19 principals), Cooperative Learning (17 mentions), gamification (7 times) and flipped learning (6 times). Other methodologies mentioned were: inquirybased learning, STEAM learning, educational robotics and programming, manipulative 
mathematics, competency work, adaptive learning, CLIL methodology, thinking-based learning, neuroeducation, mindfulness applied to education, thematic learning spaces, and learning by challenges. Virtual learning environments were also mentioned often, especially in secondary schools, and were considered a referent for pedagogical innovation. Several principals explicitly highlighted the fact that, because these methodologies depend on the teacher or the subject, an organisation can have different models. Previous studies have identified smart classrooms as appropriate places to boost active methodologies (Cebrián et al., 2020).

Personalisation of learning and boosting students' autonomy were also reported as relevant by 11 school principals, some of whom showed their awareness and considered that learning must be personalised and adaptive to be more fruitful.

The learnings are marked on the curriculum, but any centre must consider what can be done with students. What are the potentials of each one, their values and their weaknesses and respect the biological processes of evolution. (Participant 1)

Curricular flexibility is worked on by each teaching department in the way it considers most appropriate. There are no set guidelines that are general for all subjects. It is done more on an individual level and depending on the needs detected. (Participant 16)

Personalisation must not be misunderstood as isolation with students considered only as individuals to be treated independently. Personalisation can appear at both an individual level and a collective level (Lorenzo \& Gallon, 2019).

From all the interviews conducted, only two principals stated that their schools do not use new methodologies to drive students learning. So, these results suggest that the educational community would be ready for the educational shift (Zulkarnaen et al., 2019).

\section{Management systems}

The way in which principals coordinate their teams and promote communication between teachers is by using generic tools, email, and generic messaging services. Two schools used an intranet, mainly to share files or as Backoffice for their webpage and with limited functionalities. Other services are used for specific management actions such as creating schedules and calendars, booking classrooms or spaces, or cloud storage to share documents. Similar means are used with families.

Schools are not involved in integral management systems to cope with all the information management possibilities of their institutions. Rather, they prefer telephone calls and on-site meetings and traditional ways of organisation being helped by the services mentioned. The use of management systems for integrated management of learning organisations, communication between agents and building efficiency is a necessary part of the concept of smart schools (Salimi \& Ghonoodi, 2012), but innovations are still needed in Catalan schools to achieve the systemic change advocated by scholars.

\section{Initiatives for inclusion}

Architectural barriers were identified as needing action in all schools. When asked about inclusion, most interviewees pointed out that they had replaced physical barriers with ramps and lifts. Railings and door adaptations were also mentioned. Other decisions were taken in specific circumstances. 
At the level of adaptation, we have a student with severe visual impairment. Some sidewalks and stairs have been marked to make it easier for him to move. (Participant 36)

Individualisation was frequently advocated as a way for inclusion. It happens in the form of individual tutorships or in small groups. But, at the same time, it was noted that all students need to be considered in all circumstances to make a school really inclusive:

Students with special needs work with other classmates and are one more in the classroom. We try to make the school really inclusive and we organize the classes taking into account the role of all the students. (Participant 20)

By now, we have chosen to avoid as much as possible sending children out of the classroom. We prefer to place most of the reinforcements in the ordinary classroom, with the support of two teachers. (Participant 06)

Three principals noted that they depend on Intensive Supports for Inclusive Schooling teams and several thanked the work of the Psychopedagogical Advice and Guidance Teams. Some school principals even reflected awareness about the need to follow the Universal Design for Learning (UDL):

This course is already the second one that, according to the strategies of the management project specified in the Annual General Program, the Universal Design for Learning is being worked on with the help of the EAP [...] The teaching staff work to design classroom activities to reduce the barriers to participation that each class have. Thus, an attempt is made to propose different forms of engagement, representation, action and expression. (Participant 04)

At the pedagogical level, we have Intensive Support for Inclusive Schooling in Primary and in Secondary attended by individual educators and specialised teachers. We have a Department of Psychopedagogical Guidance with four people distributed in stages that ensure personalised attention for the students, and also for the coordination of the individualised plans that we have, that are elaborated in the first instance by the tutors. Our interaction with the EAP of the municipality is constant as well as specific services such as a physiotherapist from the same EAP who supports students with cerebral palsy (two cases), because we are committed to total inclusion at all levels. In addition, we also have extra support and co-teaching tutorials to better attend to the cases that require it in a personalzed way. (Participant 25)

Inclusion is the most-frequently addressed aspect of the smart school concept because of government regulation by law (Decret, 150/2017). Removal of architectural barriers is always considered, and Universal Design for Learning is used as reference framework (CAST, 2018) to indicate that school leaders care about inclusion in this sense.

\section{Facilities towards sustainability}

About two-thirds of interviewees declared that a first decision towards sustainability was the change of fluorescent and other lighting systems to LEDs. Energy consumption emerged as a second major issue, with schools having adopted more-sustainable heating (lower-energy consumption systems or heating water with biomass), altering windows, and installing insulating materials in the ceiling. Two schools have installed their own photovoltaic system: 
Solar panels have been installed in the building and, through a monitoring system, students can see the consumption of the building and the energy generated. (Participant 9)

Other topics considered to make the school more sustainable were water supply control to avoid wasting water and protocols for waste management, including composters where to deposit organic matter. The most advanced school explained a project in progress called "centralisation of all facilities in a single control panel" (Participant 35).

Principals showed concern for the environment by promoting or enforcing the use of reusable lunchboxes instead of aluminium foil and plastics, encouraging energy saving by teaching how to use appliances properly, digitalising when paper print is not necessary, promoting mobility using motorized scooters and bicycles when possible, adopting recycling habits, etc. One principal said that "we are a green school and we are already doing awareness activities, but no innovation has been made in terms of facilities" (Participant 5). Only one principal confirmed having environmental regulation:

We have transformed classroom spaces. Now classrooms incorporate mechanisms to control the temperature, the concentration of $\mathrm{CO} 2$, the automatic switching on/off of the light in classrooms and corridors. (Participant 25)

A total of 21 schools have adopted no architectural improvement to become more sustainable, or their improvements are limited or insufficient. The reason was always related to the fact that the economic management of public schools does not depend on principals. In contrast, the six partially-funded schools have implemented innovations towards environmental sustainability. Overall, there seems to be significant opportunities to engage with technologies in pursuit of sustainability that are not being explored or developed. Some principals think that they are doing a lot of sustainability work, when actually the activities are minor in comparison with actual possibilities.

\section{Reported needs, challenges and resistances}

The need for more digital devices was identified commonly by principals. They did not require sophisticated technologies, but needed basic devices such as USB, tablets, laptops, and interactive whiteboards. Wi-Fi connection was also a recurrent complaint, with 10 principals claiming that their internet access is slow or suffers from congestion and interruptions:

More USB devices are needed for children and teachers. Teachers must bring their own to be able to work from home. (Participant 1)

The devices we have are obsolete: small laptops from 10 years ago that are hard to work with. They are slow, there are websites or environments that are not compatible, and the tablets have modest features. At least an endowment of 26 laptops would be needed to work on digital competence and use them as learning tools. (Participant 7)

In 11 interviews, the need to train professionals (teachers and others) was emphasised. In general terms, the predisposition and capacity to adapt is affordable, but a lack of training arose on several occasions as a major challenge:

Limitations or resistances usually come from the fact that it is difficult for people to get out of our comfort zone. Older teachers are tired of seeing how a certain language 
or a certain principle becomes fashionable for years after being neglected. (Participant 11)

Ten principals identified a lack of economic resources. Seven referred to the need for more human resources such as a computer scientist, professionals to guide innovative projects, more teachers to organise teaching better, or more time for themselves to invest in training and become more skilled digitally. Four principals referred to adapting of the space to be more flexible and modern: "We have the technology, but the spaces, the furniture, should be adapted to the current times". (Participant 17).

The need to consider any sort of innovation within the pedagogical strategy of the school was also highlighted several times during the interviews. Technology and any improvement must be at the service of education and the human value should be predominant:

All are appropriate tools but, if they are not part of an educational project that considers why and for what we do what we do, these are just a network of tools that, yes, enriches the learning but it does not really consolidate or transform it. If I end up using ICT to give lectures to 35 students... what has changed? (Participant 25)

\section{Conclusions}

There is a huge gap between research on Industry 4.0 technologies applied to education and the impact that this research has in average schools (Mogas et al., 2020; Oke \& Fernandes, 2020). While artificial intelligence and cutting-edge technological solutions are possible with Industry 4.0 (e.g. Johnston, 2018; SmartLET, 2020), smart schools adopt more digital devices (e.g. Haria, 2020) or concrete smart services (Saini \& Goel, 2019) to different degrees (Bautista et al., 2021). Our results suggest that technology advances and implementation in education are basic. School principals reported an elementary understanding of advanced technology and positive expectations, but implementation is not yet foreseen. This can be explained by two reasons. On the one hand, not even leading companies worldwide have yet entered the Fourth Industrial Revolution (4IR) in an efficient way with meaningful results, with just very few factories (named lighthouses) are recognised by the World Economic Forum (2019). On the other hand, educational research is very focused on specific advances and so no holistic proposals of smart schools are available yet, considering the economic costs and lack of professional training.

The results from this study match previous research, which shows the need for greater efforts towards the adaptation of school buildings and the management of learning organisations to become involved in the 4IR (Mogas et al., 2020; Oke \& Fernandes, 2020). School principals generally ignored the potential of the newest technological developments largely because of a lack of awareness in relation to its advancements. Thus, policy makers and reference stakeholders should demonstrate to the educational community the positive impact of such technologies and their ease of use (OECD, 2017a). It is clear that Catalan schools do not fulfil the characteristics of web-based cyber-physical interconnected systems. Although not reporting leading innovations involving technology, their attitude is shown to be proactive: some schools consider themselves green and adopt small environmental-friendly initiatives to be conveyed to the children, but these are just very initial steps compared with all potential possibilities and environmental needs.

There is a growing number of studies of smart classrooms and smart schools, but their variety suggests a lack of a common framework and general conception. For our research, a 
new framework had to be defined based on a literature review. In addition, this research was based on a qualitative research design because our aim was a deep understanding of the smart classrooms' implementation and the challenges and opportunities gained from the viewpoint of school principals. Because the study involved one region, results cannot be generalised and, therefore, other similar studies in other regions and countries could reveal slightly different results because of the influence of policies, economic resources and the state of innovation.

Key implications for further research and action to embed smart education and technological advances within schools are drawn from this study:

- The investment in school infrastructure and equipment should be increased and should be considered from a holistic point of view as a smart school.

- Because school principals have limited understanding and vision of smart schools' potentialities and benefits, training and professional development programmes in smart education are needed to help them in the process of implementation.

- The leadership of teachers is key to achieving the ideal of smart education, because teachers are in charge of leading change and innovation within their classrooms, including the smart use of technology, the use of smart learning management systems, the rethinking methodologies with the potentialities of these new resources.

- The ethical implications of the implications from Industry 4.0 in education must be better defined.

- The implementation of smart classrooms must go hand in hand with the development of life skills such as critical thinking, active engagement, and empowerment to promote individual and collective development.

- Industry 4.0 must develop educational technologies and make them available to smart schools: improvements in artificial intelligence, cloud computing and Internet of Things are needed to produce a clear impact in smart education, with solutions being accessible and easy to use.

Funding Open Access funding provided thanks to the CRUE-CSIC agreement with Springer Nature. This publication has been possible with the support of the Secretaria d'Universitats i Recerca del Departament d'Economia i Coneixement de la Generalitat de Catalunya, the European Union (EU) and the European Social Fund (ESF) (funding reference number: 2017 FI_B 00085).

Open Access This article is licensed under a Creative Commons Attribution 4.0 International License, which permits use, sharing, adaptation, distribution and reproduction in any medium or format, as long as you give appropriate credit to the original author(s) and the source, provide a link to the Creative Commons licence, and indicate if changes were made. The images or other third party material in this article are included in the article's Creative Commons licence, unless indicated otherwise in a credit line to the material. If material is not included in the article's Creative Commons licence and your intended use is not permitted by statutory regulation or exceeds the permitted use, you will need to obtain permission directly from the copyright holder. To view a copy of this licence, visit http://creativecommons.org/licenses/by/4.0/.

\section{References}

Abdel-Basset, M., Manogaran, G., Mohamed, M., \& Rushdy, E. (2019). Internet of Things in smart education environment: Supportive framework in the decision-making process. Concurrency Computation Practice and Experience, 31(10), e4515. https://doi.org/10.1002/cpe.4515

Anwar, S., Bascou, N. A., Menekse, M., \& Kardgar, A. (2019). A systematic review of studies on educational robotics. Journal of Pre-College Engineering Education Research, 9(2), art. 2. https://doi.org/ $10.7771 / 2157-9288.1223$ 
Bacca, J., Baldiris, S., Fabregat, R., Graf, S., \& Kinshuk. (2014). Augmented reality trends in education: A systematic review of research and applications. Educational Technology \& Society, 17(4), 133-149.

Bautista, G., Rubio, M. J., \& Sánchez, A. (2021). Towards smart learning spaces in Catalan schools: Teachers' perceptions of change. Learning Environments Research. https://doi.org/10.1007/ s10984-021-09357-y

Booth, T., \& Ainscow, M. (2002). Index for inclusion: Developing learning and participation in schools. Centre for Studies on Inclusive Education (CSIE). https://www.eenet.org.uk/resources/docs/Index\% 20English.pdf.

Bransford, J., Vye, N., \& Bateman, H. (2004). Creating high-quality learning environments: Guidelines from research on how people learn. In National Research Council (Ed.), The knowledge economy and postsecondary education: Report of a workshop (pp. 159-198). The National Academies Press. https:// doi.org/10.17226/10239.

Braun, V., \& Clarke, V. (2006). Using thematic analysis in psychology. Qualitative Research in Psychology, 3, 77-101. https://doi.org/10.1191/1478088706qp063oa

Brenes, M., Gronenberg, P., Henniges, J., Pfoertner, K., Robinson, P., Tesni, S., \& Ullucci, R. (2018). My right is our future: The transformative power of disability-inclusive education. CBM. https://www. cbm.org/article/downloads/54741/DID_Series_-\%20_Book_3.pdf.

Bryk, A. S., Sebring, P. B., Allensworth, E., Luppescu, S., \& Easton, J. Q. (2009). Organizing schools for improvement: Lessons from Chicago. University of Chicago Press. https://doi.org/10.7208/chicago/ 9780226078014.001 .0001

Camacho, M. (2019). Samsung Smart School 2017-18: Centros digitalmente competentes. https://images. samsung.com/is/content/samsung/p5/es/docs/smart-school-guia.pdf.

CAST (2018). Universal design for learning guidelines version 2.2. http://udlguidelines.cast.org.

Cebrián, G., Palau, R., \& Mogas, J. (2020). The Smart Classroom as a means to the development of ESD methodologies. Sustainability, 12(7), 3010. https://doi.org/10.3390/su12073010

Cho, E., Cho, Y. H., Grant, M. M., Song, D., \& Huh, Y. (2020). Trends of educational technology in Korea and the US: A Report on the AECT-Korean Society for Educational Technology (KSET) panel discussion. TechTrends, 64(3), 357-360. https://doi.org/10.1007/s11528-020-00493-5

Creswell, J. W. (2007). Qualitative inquiry and research design: Choosing among five approaches (2nd ed.). SAGE Publications, Inc.

de Freitas, E., Rousell, D., \& Jäger, N. (2019). Relational architectures and wearable space: Smart schools and the politics of ubiquitous sensation. Research in Education. https://doi.org/10.1177/0034523719 883667

Decret 150/2017, de 17 d'octubre, de l'atencióeducativa a l'alumnatenel marc d'un Sistema educatiuinclusiu. Diari Oficial de la Generalitat de Catalunya, 17 d'octubre de 2017, núm. 7477. https://portaldogc. gencat.cat/utilsEADOP/PDF/7477/1639866.pdf.

Denzin, N. K., \& Lincoln, Y. S. (2011). Introduction: The discipline and practice of qualitative research. In N. K. Denzin \& Y. S. Lincoln (Eds.), The SAGE handbook of qualitative research (4th ed., pp. 1-19). SAGE Publications, Inc.

Dneprovskaya, N. V., Komleva, N. V., \& Urintsov A. I. (2020). The knowledge management approach to digitalization of smart education. In Z. Hu, S. Petoukhov, \& M. He (Eds.), Advances in artificial systems for medicine and education II: Advances in intelligent systems and computing, 902. Springer. https://doi.org/10.1007/978-3-030-12082-5_58

Education Endowment Foundation. (2018). Teaching and learning toolkit: An accessible summary of the international evidence on teaching 5-16 year-olds. https://educationendowmentfoundation.org.uk/public/files/Toolkit/complete/EEF-Teaching-Learning-Toolkit-October-2018.pdf.

El Hajji, M., Es-saady, Y., OueldGuejdi, A., \& Douzi, H. (2019). A framework for smart academic guidance using educational data mining. Education and Information Technologies, 24(2), 1379-1393. https:// doi.org/10.1007/s10639-018-9838-8

El Mrabet, H., \& Moussa, A. A. (2019). Smart school guidance and vocational guidance system through the Internet of Things. In Proceedings of the 2nd International Conference on Networking, Information Systems \& SecurityMarch, Article 70, 1-5. https://doi.org/10.1145/3320326.3320404

Elkoubaiti, H., \& Mrabet, R. (2018). How are augmented and virtual reality used in smart classrooms? ACM International Conference Proceeding Series. https://doi.org/10.1145/3289100.3289131

European Commission. (2020). Artificial intelligence (AI): Artificial intelligence research, funding, policy and related publications.https://ec.europa.eu/info/research-and-innovation/research-area/industrialresearch-and-innovation/key-enabling-technologies/artificial-intelligence-ai_en.

Eyal, L., \& Gil, E. (2020). Design patterns for teaching in academic settings in future learning spaces. British Journal of Educational Technology, 51(4), 1061-1077. https://doi.org/10.1111/bjet.12923 
Flick, U., von Kardorff, E., \& Steinke, I. (Eds.). (2004). A companion to qualitative research. SAGE Publications Ltd.

Generalitat de Catalunya. (2019).Educació vol situar Catalunya com un paíscapdavanterenl'úseducatiu de la tecnologia per l'èxit escolar i social del seualumnat. http://ensenyament.gencat.cat/ca/inici/notapremsa/?id=380962

Generalitat de Catalunya. (2020). Catalonia.AI, L'Estratègiad'Intel-ligència Artificial de Catalunya. http:// politiquesdigitals.gencat.cat/ca/tic/catalonia-ai.

Gilman, E., Tamminen, S., Yasmin, R., Ristimella, E., Peltonen, E., Harju, M., Lovén, L., Riekki, J., \& Pirttikangas, S. (2020). Internet of Things for smart spaces: A university campus case study. Sensors, 20, 3716. https://doi.org/10.3390/s20133716

Gu, Q., \& Johansson, O. (2013). Sustaining school performance: School contexts matter. International Journal of Leadership in Education, 16(3), 301-326. https://doi.org/10.1080/13603124.2012.732242

Haria, S. L. G. (2020). Iken Smart Classroom. https://www.lghsvapi.edu.in/content/iken-smart-classroom.

Hassan, M., \& Geys, B. (2016). Who should pick up the bill? Distributing the financial burden of technological innovations in schools. Computers \& Education, 94, 193-203. https://doi.org/10.1016/j.compe du.2015.11.018

Hill, S. B., Wilson, S., \& Watson, K. (2004). Learning ecology: A new approach to learning and transforming ecological consciousness: Experiences from social ecology in Australia. In E. V. O’Sullivan \& M. Taylor (Eds.), Learning toward an ecological consciousness: Selected transformative practices (pp. 47-64). Palgrave Macmillan.

Hoel, T., \& Mason, J. (2018). Standards for smart education-Towards a development framework. Smart Learning Environments, 5, 3. https://doi.org/10.1186/s40561-018-0052-3

Huang, R., Yang, J., \& Zheng, L. (2013). The components and functions of smart learning environments for easy, engaged and effective learning. International Journal for Educational Media and Technology, $7(1), 4-14$.

Humayun, M. (2020). Role of emerging IoT big data and cloud computing for real time application. International Journal of Advanced Computer Science and Applications, 11(4), 494-506. https://doi.org/10. 14569/IJACSA.2020.0110466

IBM Global Education. (2009). Education for a smarter planet: The future of learning. executive insights.

Ibrahim, M. S., Razak, A. Z. A., \& Kenayathulla, H. B. (2013). Smart principals and smart schools. Procedia Social and Behavioral Sciences, 103, 826-836. https://doi.org/10.1016/j.sbspro.2013.10.404

Ifenthaler, D., \& Schweinbenz, V. (2016). Students' acceptance of tablet PCs in the classroom. Journal of Research on Technology in Education, 48(4), 306-321. https://doi.org/10.1080/15391523.2016.12151 72

Johnston, J. (2018). Are 'Smart' Classrooms the future? https://campustechnology.com/articles/2018/10/31/ are-smart-classrooms-the-future.aspx.

Karampa, V., \& Paraskeva, F. (2020). Smart Learning Environments: A blend of ICT achievements and smart pedagogy for the world sustainable development. In T. Ahram, R. Taiar, S. Colson, \& A. Choplin (Eds), Human interaction and emerging technologies. IHIET 2019. Advances in intelligent systems and computing, vol 1018. Springer, Cham. https://doi.org/10.1007/978-3-030-25629-6_75

Koper, R. (2014). Conditions for effective smart learning environments. Smart Learning Environments, $1,5$. https://doi.org/10.1186/s40561-014-0005-4

Kozma R. B., \& Vota W. S. (2014). ICT in developing countries: Policies, implementation, and impact. In J. Spector, M. Merrill, J. Elen, \& M. Bishop (Eds), Handbook of research on educational communications and technology. Springer. https://doi.org/10.1007/978-1-4614-3185-5_72

Kvale, S., \& Brinkmann, S. (2009). Interviews: Learning the craft of qualitative research interviewing (2nd ed.). SAGE Publications, Inc.

LG CNS. (2014). A step closer to educational equality with ICT and smart schools. www.lgcnsblog.com/ features/a-step-closer-to-educational-equality-with-ict-and-smart-schools/\#sthash.vL082V1H.dpbs.

Li, H., Li, H., Zhang, S., Zhong, Z., \& Cheng, J. (2019). Intelligent learning system based on personalized recommendation technology. Neural Computing and Applications, 31(9), 4455-4462. https://doi.org/ 10.1007/s00521-018-3510-5

Liang, J. M., Su, W. C., Chen, Y. L., Wu, S. L., \& Chen, J. J. (2020). Smart interactive education system based on wearable devices. Sensors, 19, 3260. https://doi.org/10.3390/s19153260

Lorenzo, N., \& Gallon, R. (2019). Smart Pedagogy for Smart Learning. In Daniela L. (Ed.), Didactics of smart pedagogy (pp. 41-69). Springer, Cham. https://doi.org/10.1007/978-3-030-01551-0_3

Lorenzo, N., Gallon, R., Palau, R., \& Mogas, J. (2021). New objectives for smart classrooms from industry 4.0. Technology, Knowledge and Learning. https://doi.org/10.1007/s10758-021-09527-0 
Lyapina, I., Sotnikova, E., Lebedeva, O., Makarova, T., \& Skvortsova, N. (2019). Smart technologies: Perspectives of usage in higher education. International Journal of Educational Management, 33(3), 454461. https://doi.org/10.1108/IJEM-08-2018-0257

Maas, M. J., \& Hughes, J. M. (2020). Virtual, augmented and mixed reality in K-12 education: A review of the literature. Technology, Pedagogy and Education, 29(2), 231-249. https://doi.org/10.1080/14759 39X.2020.1737210

Means, A. J. (2018). Learning to save the future: Rethinking education and work in an era of digital capitalism. Routledge. https://doi.org/10.4324/9781315450209

Minichiello, V., Aroni, R., Timewell, E., \& Alexander, L. (1990). In-Depth Interviewing: Researching people. Longman Cheshire.

Mogas, J., Palau, R., Lorenzo, N., \& Gallon, R. (2020). Developments for smart classrooms: Schools' perspective and needs. International Journal of Mobile and Blended Learning, 12(4), 34-50. https://doi. org/10.4018/IJMBL.2020100103

Moore, S. L., \& Ellsworth J. B. (2014). Ethics of educational technology. In J. Spector, M. Merrill, J. Elen, \& M. Bishop (Eds), Handbook of research on educational communications and technology. Springer. https://doi.org/10.1007/978-1-4614-3185-5_10

New York Smart Schools. (2014). New York smart schools: Commission report. https://www.governor. ny.gov/sites/governor.ny.gov/files/archive/governor_files/SmartSchoolsReport.pdf.

Ng, H. S. (2020). Opportunities, challenges, and solutions for industry 4.0. In A. Özbebek Tunç, \& P. Aslan (Eds.), Business management and communication perspectives in industry 4.0 (pp. 32-51). Hershey. https://doi.org/10.4018/978-1-5225-9416-1.ch003

Nosalska, K., Piątek, Z. M., Mazurek, G., \& Rządca, R. (2019). Industry 4.0: Coherent definition framework with technological and organizational interdependencies. Journal of Manufacturing Technology Management. https://doi.org/10.1108/JMTM-08-2018-0238

OECD. (2017a). Schools at the crossroads of innovation in cities and regions. OECD Publishing. https:// doi.org/10.1787/9789264282766-en

OECD. (2017b). The OECD handbook for innovative learning environments. OECD Publishing. https:// doi.org/10.1787/9789264277274-en

Oke, A., \& Fernandes, F. A. P. (2020). Innovations in teaching and learning: Exploring the perceptions of the education sector on the 4th industrial revolution (4IR). Journal of Open Innovation: Technology, Market, and Complexity, 6(2), 31.

Omidinia, S., Masrom, M., \& Selamat, H. (2012). Determinants of smart school system success: A case study of Malaysia. International Journal of Academic Research, 4(1), 29-36.

Paniagua, A., \& Istance, D. (2018). Teachers as designers of learning environments: The importance of innovative pedagogies. OECD Publishing. https://doi.org/10.1787/9789264085374-en

Papadopoulos, I., Lazzarino, R., Miah, S., Weaver, T., Thomas, B., \& Koulouglioti, C. (2020). A systematic review of socially assistive robots in pre-tertiary education. Computers \& Education, 155, 103924. https://doi.org/10.1016/j.compedu.2020.103924

Pocero, L., Amaxilatis, D., Mylonas, G., \& Chatzigiannakis, I. (2017). Open source IoT meter devices for smart and energy-efficient school buildings. HardwareX, 1, 54-67. https://doi.org/10.1016/j. ohx.2017.02.002

Raes, A., Detienne, L., Windey, I., \& Depaepe, F. (2019). A systematic literature review on synchronous hybrid learning: Gaps identified. Learning Environments Research. https://doi.org/10.1007/ s10984-019-09303-Z

Renz, A., \& Hilbig, R. (2020). Prerequisites for artificial intelligence in further education: identification of drivers, barriers, and business models of educational technology companies. International Journal of Educational Technology in Higher Education, 17, art. 14. https://doi.org/10.1186/ s41239-020-00193-3

Rodal, E. (2020). Industria 4.0: Conceptos, tecnologías habilitadoras y retos. Ediciones Pirámide.

Roll, I., \& Wylie, R. (2016). Evolution and revolution in artificial intelligence in education. International Journal of Artificial Intelligence in Education, 26(2), 582-599. https://doi.org/10.1007/ s40593-016-0110-3

Sah, P., Fanselow, M., Hattie, J., Magsamen, S., Mattingley, J., Quirk, G., \& Williams, S. (2016). Integrating neuroscience and learning: now's the time... NPJ Science of Learning, 1, 16007. https://doi. org/10.1038/npjscilearn.2016.7

Saini, M. K., \& Goel, N. (2019). How smart are smart classrooms? A review of smart classroom technologies. ACM Computing Surveys, 52(6), 130. https://doi.org/10.1145/3365757

Salimi, L., \& Ghonoodi, A. (2012). WCLTA 2011 The study of functional elements of management system in smart schools. Procedia Social and Behavioral Sciences, 31, 140-144. https://doi.org/10. 1016/j.sbspro.2011.12.031 
Schwab, K. (2017). The fourth industrial revolution. Crown Publishers.

Senge, P. M. (2006). The fifth discipline: The art \& practice of the learning organization (Revised \& Updated edition). Doubleday.

Silverman, D. (2006). Interpreting qualitative data (3rd ed.). SAGE Publications Ltd.

Sleegers, P. J. C., Moolenaar, N. M., Galetzka, M., Pruyn, A., Sarroukh, B. E., \& van der Zande, B. (2013). Lighting affects students' concentration positively: Findings from three Dutch studies. Lighting Research \& Technology, 45(2), 159-175. https://doi.org/10.1177/1477153512446099

SmartLET. (2020). SmartLET: Learning analytics to enhance the design and orchestration in scalable, IoT-enriched, and ubiquitous Smart Learning Environments.

Spector, J. M. (2016). Ethics in educational technology: Towards a framework for ethical decision making in and for the discipline. Educational Technology Research and Development, 64, 1003-1011. https://doi.org/10.1007/s11423-016-9483-0

Sun, J. C. Y., \& Hsu, K. Y. C. (2019). A smart eye-tracking feedback scaffolding approach to improving students' learning self-efficacy and performance in a C programming course. Computers in Human Behavior, 95, 66-72. https://doi.org/10.1016/j.chb.2019.01.036

ten Bruggencate, G., Luyten, H., Scheerens, J., \& Sleegers, P. (2012). Modeling the influence of school leaders on student achievement: How can school leaders make a difference? Educational Administration Quarterly, 48(4), 699-732. https://doi.org/10.1177/0013161X11436272

United Nations. (2012). The future we want: Outcome document adopted at Rio+20. https://sustainabledeve lopment.un.org/futurewewant.html.

United Nations. (2019). Sustainable development goals: The 2030 Agenda for Sustainable Development. https://www.un.org/sustainabledevelopment/education/.

Vincent-Lancrin, S., Urgel, J., Kar, S., \& Jacotin, G. (2019). Measuring innovation in education 2019: What has changed in the classroom? OECD Publishing. https://doi.org/10.1787/9789264311671-en

World Economic Forum. (2019). Fourth industrial revolution: Beacons of technology and innovation in manufacturing. http://www3.weforum.org/docs/WEF_4IR_Beacons_of_Technology_and_Innovation_ in_Manufacturing_report_2019.pdf.

Wu, D., Zhou, C., Meng, C., Wang, H., Chen, M., Lu, C., \& Xu, J. (2019). Research on the status quo of smart school development in China. In M. Chang et al. (Eds.), Foundations and trends in smart learning (pp. 181-186). Springer. https://doi.org/10.1007/978-981-13-6908-7_26

Zawacki-Richter, O., Marín, V. I., Bond, M., \& Gouverneur, F. (2019). Systematic review of research on artificial intelligence applications in higher education-Where are the educators? International Journal of Educational Technology in Higher Education, 16, 39. https://doi.org/10.1186/s41239-019-0171-0

Zhang, J., Yang, J., Chang, M., \& Chang, T. (2016). Towards a critical understanding to the best practices of ICT in K-12 education in global context. In J. Zhang, J. Yang, M. Chang, \& T. Chang (Eds.), ICT in education in global context. lecture notes in educational technology. Springer. https://doi.org/10.1007/ 978-981-10-0373-8_1

Zhang, S., Shi, J., \& Hu, Y. (2019). Research and design of intelligent learning system based on recommendation technology. Mechatronic Systems and Control, 47(1), 43-49. https://doi.org/10.2316/J.2019. 201-2968

Zhong, R. Y., Xu, X., Klotz, E., \& Newman, S. T. (2017). Intelligent manufacturing in the context of industry 4.0: A review. Engineering, 3(5), 616-630. https://doi.org/10.1016/J.ENG.2017.05.015

Zhu, Z. T., Yu, M. H., \& Riezebos, P. (2016). A research framework of smart education. Smart Learning Environments, 3(1), 4. https://doi.org/10.1186/s40561-016-0026-2

Zulkarnaen, R. H., Setiawan, W., Rusdiana, D., \& Muslim, M. (2019). Smart city design in learning science to grow 21st century skills of elementary school student. Journal of Physics: Conference Series, 157(2), 022021. https://doi.org/10.1088/1742-6596/1157/2/022021

Publisher's Note Springer Nature remains neutral with regard to jurisdictional claims in published maps and institutional affiliations. 